\title{
Quantitative analyses of ammonia-oxidizing Archaea and bacteria in the sediments of four nitrogen-rich wetlands in China
}

\author{
Shanyun Wang $\cdot$ Yu Wang $\cdot$ Xiaojuan Feng • \\ Liming Zhai $\cdot$ Guibing Zhu
}

Received: 3 November 2010 /Revised: 26 December 2010/Accepted: 27 December 2010 /Published online: 21 January 2011

(C) Springer-Verlag 2011

\begin{abstract}
With the rapid development of ammoniasynthesizing industry, the ammonia-nitrogen pollution in wetlands acting as the sink of point and diffuse pollution has been increased dramatically. Most of ammonia-nitrogen is oxidized at least once by ammonia-oxidizing prokaryotes to complete the nitrogen cycle. Current research findings have expanded the known ammonia-oxidizing prokaryotes from the domain Bacteria to Archaea. However, in the complex wetlands environment, it remains unclear whether ammonia oxidation is exclusively or predominantly linked to Archaea or Bacteria as implied by specific high abundance. In this research, the abundance and composition of Archaea and Bacteria in sediments of four kinds of wetlands with different nitrogen concentration were investigated by using quantitative real-time polymerase chain reaction, cloning, and sequencing approaches based on amoA genes. The results indicated that AOA distributed widely in wetland sediments, and the phylogenetic tree
\end{abstract}

Electronic supplementary material The online version of this article (doi:10.1007/s00253-011-3090-0) contains supplementary material, which is available to authorized users.

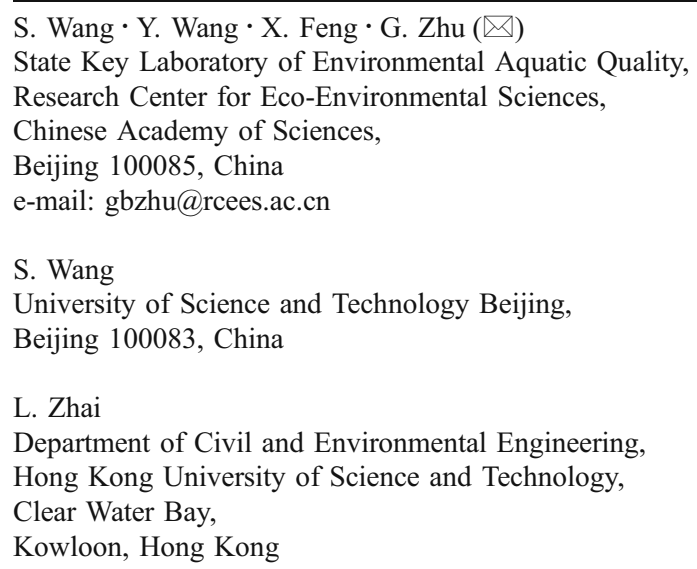

revealed that archaeal amoA functional gene sequences from wetlands sediments cluster as two major evolutionary branches: soil/sediment and sediment/water. The bacteria functionally dominated microbial ammonia oxidation in different wetlands sediments on the basis of molecule analysis, potential nitrification rate, and soil chemistry. Moreover, the factors influencing AOA and AOB abundances with environmental indicator were also analyzed, and the results addressed the copy numbers of archaeal and bacterial amoA functional gene having the higher correlation with $\mathrm{pH}$ and ammonia concentration. The $\mathrm{pH}$ had relatively great negative impact on the abundance of AOA and $\mathrm{AOB}$, while ammonia concentration showed positive impact on AOB abundance only. These findings could be fundamental to improve understanding of the importance of $\mathrm{AOB}$ and $\mathrm{AOA}$ in nitrogen and other nutrients cycle in wetland ecosystems.

Keywords Wetland - Sediment - Abundance - Biodiversity amoA functional gene

\section{Introduction}

Microbial nitrogen cycle is the fundamental and most important process in natural cycle, of which ammonia oxidation process is rate-limiting step. For decades, only specific groups of ammonia-oxidizing bacteria (AOB) have been found to possess nitrification capacity among prokaryotes (Prosser et al. 1989). With findings of key functional gene (ammonium monooxygenase, amoA) in Crenarchaeota (Venter et al. 2004), Könneke has successfully isolated an autotrophic ammonia-oxidizing marine archaeon Nitrosopumilus maritimus (Könneke et al. 2005). In the past few years, ammonia-oxidizing Archaea (AOA) has been 
reported extensively, which is found in marine waters (Francis et al. 2005), soil (Leininger et al. 2006), bioreactor (Park et al. 2006), hotspring (Zhang et al. 2008), and so on, the conventional rate-limiting step has been re-evaluated (Nicol and Prosser 2008).

Wetland is viewed as "Kidney of the Nature" owing to its rich sources, unique ecological structure and functions (Verhoeven et al. 2006), which is also an important media for microbial nitrogen cycle (Gruber and Galloway 2008). In the last decade, with rapid economic growth and population explosion, the ammonia-nitrogen pollution in all kinds of wetlands which acting as "sink" increases dramatically, and results in a series of environmental problem such as aquatic eutrophication (Peng and Zhu 2006; Zhu et al. 2008) and nitrous oxide emission (Wang et al. 2006; 2007).

Rebalancing the nitrogen cycle is the key to control the nitrogen pollution, of which the critical process is nitrification that relies on ammonia-oxidizing microorganisms. As the only two nitrifying communities, the composition and abundance of archaeal and bacterial amo $A$ gene has been extensively studied in various ecosystems recently; the results show AOA or AOB drives the nitrification process to varying degrees in different ecosystems. The significance of AOA based on nitrification predominates over AOB in marine sediments and soils (Wuchter et al. 2006; Leininger et al. 2006). In contrast, higher abundance of bacterial amoA genes has been reported only in a few environments, such as estuary (Caffrey et al. 2007), sediments of coastal (Mosier and Francis 2008, Santoro et al. 2008), salinity lake (Jiang et al. 2009), and soils in higher altitude (Zhang et al. 2009). Zhu' studies also showed the bacterial predominance in nitrogen-polluted river sediments (Fan et al. 2010); however, it is unclear whether nitrification with high ammonia strength is exclusively or predominantly linked to bacteria as implied by their abundance. Moreover, the mere presence of archaeal or bacterial amoA genes may not necessarily reflect functional activity of archaeal or bacterial ammonia oxidation.

Further exploration on the behavior of ammoniaoxidizing bacteria and Archaea in sediments is of great importance for understanding the function of wetlands nitrogen cycle. Hence, the aim of the present study was especially devoted to investigate the role of $\mathrm{AOA}$ and $\mathrm{AOB}$ in wetland sediments and assess the relationship of AOA and $\mathrm{AOB}$ abundance with environmental factors of different wetlands with high spatial heterogeneity conditions. Also, another objective of this study was to compare the community composition of AOA in wetland sediments because of their potential importance in the nitrogen cycling. To achieve these goals, sediment samples were collected from four different kinds of nitrogen-polluted wetland sediments, paddy field (Jiaxing Paddy Field), lake wetland (Baiyangdian Lake), tidal wetland (Red Beach), and swamp wetland (Freshwater Marsh). The abundances of $\mathrm{AOB}$ and $\mathrm{AOA}$ were quantified with real-time polymerase chain reaction (Q-PCR) techniques, and the community compositions of AOA were analyzed by cloning and sequencing amoA gene clone libraries. Meanwhile, the environmental factors (e.g., $\mathrm{NH}_{4}^{+}-\mathrm{N}, \mathrm{pH}, \mathrm{NO}_{3}{ }^{-} \mathrm{N}$, etc.) and potential nitrification rates were measured, and correlation analysis was conducted in combination with Q-PCR assay.

\section{Materials and methods}

\section{Field sampling}

Four nitrogen-rich wetlands in China were chosen as field experimental sites. Red Beach, located at the Dawa county of Liaoning Province $\left(40^{\circ} 41^{\prime} \sim 41^{\circ} 27^{\prime} \mathrm{N}, 121^{\circ} 31^{\prime} \sim 122^{\circ} 28^{\prime} \mathrm{E}\right)$, is the world's most well-preserved and Chinese largest wetland. Now, it's known as a pure green eco-tourism system. Freshwater marsh is located in Panjin city of Liaoning Province $\left(40^{\circ} 39^{\prime} \sim 41^{\circ} 27^{\prime} \mathrm{N}, 121^{\circ} 25^{\prime} \sim 122^{\circ} 31^{\prime} \mathrm{E}\right)$ at water level of $0-6.5 \mathrm{~m}$ above sea level. It is a sedimentary plain at downstream of five rivers. Baiyangdian Lake in Anxin county of Hebei Province $\left(38^{\circ} 53^{\prime} 31 \mathrm{~N}, 116^{\circ} 11^{\prime} 08 \mathrm{E}\right)$ is the largest natural freshwater lake in North of China. It's a eutrophic lake and perennially suffered from the sewage and wastewater of Baoding city and agricultural runoff. Paddy field is located in Jiaxing city of Zhejiang Province $\left(30^{\circ} 45^{\prime} 14 \mathrm{~N}, 120^{\circ} 45^{\prime} 30 \mathrm{E}\right)$. The site, as long-term fertilized paddy soil, represents a typical agricultural rice planting region of subtropical China. A longterm fertilization with the practice of feeding livestock waste has been established for more than 25 years with a rice-cole rotation system. Each fresh sediment sample $(0-20 \mathrm{~cm})$ was collected at $24 \pm 2{ }^{\circ} \mathrm{C}$ in 2009 and was sealed in a sterile plastic bag stored in an ice cooler and brought back to the laboratory. One part was stored at $4{ }^{\circ} \mathrm{C}$ for possible incubation experiments, the others pre-filtered through a $2.0-\mathrm{mm}$ sieve and then stored at $4{ }^{\circ} \mathrm{C}$ for chemical analysis, and the subsamples were stored at $-80{ }^{\circ} \mathrm{C}$ for DNA extraction. The chemical characteristics of sediments in the four wetlands are listed in Table 1.

Sediment chemical analysis

Total organic matters, total Kjeldahl nitrogen, and water content of sediment samples were determined according to standard methods (Bao, 2000). Five grams dry sediment mixed well with $12.5 \mathrm{~mL}$ UltraPure water (a soil-to-water ratio of $1: 2.5$ ) was subjected to $\mathrm{pH}$ measurement $(\mathrm{pH}-$ Meter, Delta 320, METTLER TOLEDO, USA). $\mathrm{NH}_{4}{ }^{+}-\mathrm{N}$ 
Table 1 The chemical characteristics of sediment in four wetlands total Kjeldahl nitrogen

\begin{tabular}{lllllll}
\hline & $\begin{array}{l}\mathrm{TOM} \\
\left(\mathrm{g} \mathrm{kg}^{-1}\right)\end{array}$ & $\begin{array}{l}\mathrm{NH}_{4}^{+}-\mathrm{N} \\
\left(\mathrm{mg} \mathrm{kg}^{-1}\right)\end{array}$ & $\begin{array}{l}\mathrm{NO}_{\mathrm{x}}^{-}-\mathrm{N} \\
\left(\mathrm{mg} \mathrm{kg}^{-1}\right)\end{array}$ & $\begin{array}{l}\mathrm{TKN} \\
\left(\mathrm{g} \mathrm{kg}^{-1}\right)\end{array}$ & $\mathrm{pH}$ & $\begin{array}{l}\text { Water content } \\
\%\end{array}$ \\
\hline Red Beach & 12.58 & 14.20 & 13.60 & 1.95 & 8.39 & 37.21 \\
Freshwater Marsh & 11.46 & 49.40 & 9.10 & 1.90 & 8.37 & 38.25 \\
Baiyangdian Lake & 12.15 & 96.49 & 14.77 & 2.14 & 8.22 & 37.58 \\
Paddy Field & 32.59 & 147.48 & 40.28 & 3.76 & 8.20 & 26.35 \\
\hline
\end{tabular}

and $\mathrm{NO}_{\mathrm{x}}{ }^{-}-\mathrm{N}$ were extracted with $2 \mathrm{M} \mathrm{KCl}$ and measured by a continuous flow analyzer (SAN plus, Skalar Analytical B. V., The Netherlands). Triplicates were made for QA/QC.

\section{DNA extraction}

Sediment DNA were extracted from $0.35 \mathrm{~g}$ of freeze-drying soil using a Fast Soil DNA isolation kit (Qbiogene, Carlsbad, CA) according to the manufacturer's protocol with minor modifications: the Lysing Matrix E tubes were homogenized in the FastPrep ${ }^{\mathrm{TM}}$ Instrument (Bio 101, Thermo) and vortexed at a speed setting of 5.5 for $45 \mathrm{~s}$, and then the tubes were centrifuged at $14000 \times g$ for another $15 \mathrm{~min}$ to pellet detris. Then, the protocol strictly was followed. The consequent sediment DNA were eluted with $75 \mu \mathrm{l}$ of DES (DNase/pyrogen-free water) and stored at $-20{ }^{\circ} \mathrm{C}$ until use.

PCR, cloning, and sequence analysis

Primer pairs amoA-1F/amoA-2R and Arch-amoAF/ArchamoAR were used for bacterial and archaeal $a m o A$ genes PCR, following related PCR amplification protocols (He et al. 2007; Francis et al. 2005). The PCR product was gelpurified and ligated into the pGEM-T Easy Vector (Promega, Madison, WI). The resulting ligation products were used to transform Escherichia coli JM109 competent cells following manufacturer instructions. PCR-screened directly for the presence of inserts by using T7 and SP6 vector primers, the amplicons were analyzed by restriction with restriction endonuclease Hha I (TAKARA, Dalian, China). Restriction digestion was carried out in a total volume of $20 \mu \mathrm{L}$ including $5 \mathrm{U}$ restriction enzymes and $4 \mu \mathrm{L}$ PCR products, and the system was incubated for $2 \mathrm{hrs}$ at $37{ }^{\circ} \mathrm{C}$. Digested DNA fragments were analyzed by fragments separation on a $2 \%(w / v)$ agarose gel and visualized with a GBOX/HR-E-M (Syngene, UK). Representative clones from each digestion pattern were selected for sequencing using an ABI 3730XL automated sequencer. Other positive clones were selected to isolate plasmid DNA using a GeneJet Plasmid Miniprep Kit (Fermentas MBI, Lithuania) as amoA gene standards. The plasmid DNA concentration was determined on a Nanodrops ND-1000 UV-Vis Spectrophotometer (NanoDrop Technologies,
Wilmington, DE, USA) for calculation of amoA gene copy number. All the sequences and their relatives obtained from the NCBI BLAST were aligned by using Clustal X1.83 program (Thompson et al. 1997). The sequences sharing 99\% similarity were grouped into the same operational taxonomic unit (OTU) using software DOTUR (Schloss et al. 2005) by the furthest neighbor approach. The biodiversity indicator (Shannon and Chao 1) were also calculated with DOTUR software. Phylogenetic trees were constructed by neighbor-joining (NJ) with the Jukes-Cantor correction in MEGA 4 package (Tamura et al. 2007).

\section{Real-time quantitative PCR}

The same primer pairs were applied on real-time PCR assays as described above. Amplification and detection were carried out with an ABI Prism 7300 Sequence Detection System (Applied Biosystems, Foster City, CA) as follows: $50{ }^{\circ} \mathrm{C}$ for $2 \mathrm{~min}, 95^{\circ} \mathrm{C}$ for $30 \mathrm{~s}$, followed by 40 cycles of $10 \mathrm{~s}$ at $95{ }^{\circ} \mathrm{C}, 30 \mathrm{~s}$ at $53{ }^{\circ} \mathrm{C}$, and $55^{\circ} \mathrm{C}$ for AOA and $\mathrm{AOB}$, respectively, $1 \mathrm{~min}$ at $72{ }^{\circ} \mathrm{C}$. The $25-\mu \mathrm{L}$ reaction volume contained $12.5 \mu \mathrm{L}$ SYBRs Premix Ex Taq (TAKARA, Dalian, China), 200nM of each AOB primer, or $200 \mathrm{nM}$ each of AOA primer and $2 \mu \mathrm{L}$ of tenfold-diluted DNA as a template. Tenfold serial dilutions of a known copy number of the plasmid DNA were subjected to realtime PCR in triplicate to generate an external standard curve. The results with efficiency and correlation coefficient above $95 \%$ and 0.98 were employed.

Ammonia oxidation potential

The measurement was carried on using a chlorate inhibition method according to Kurola et al. (2005). Briefly, $5.0 \mathrm{~g}$ of fresh soil was added to $50-\mathrm{mL}$ centrifuge tube containing $20 \mathrm{~mL}$ phosphate buffer solution (in $\mathrm{g} \mathrm{L}^{-1}, \mathrm{NaCl}, 8.0 ; \mathrm{KCl}$, $\left.0.2 ; \mathrm{Na}_{2} \mathrm{HPO}_{4}, 0.2 ; \mathrm{NaH}_{2} \mathrm{PO}_{4}, 0.2 ; \mathrm{pH} 7.4\right)$ with $1 \mathrm{mM}$ $\left(\mathrm{NH}_{4}\right)_{2} \mathrm{SO}_{4}$. Potassium chlorate with a final concentration of $10 \mathrm{mM}$ was added to inhibit the nitrite oxidation. The suspension was incubated in dark at $25^{\circ} \mathrm{C}$ for $24 \mathrm{~h}$, and nitrite was extracted with $5 \mathrm{~mL}$ of $2 \mathrm{M} \mathrm{KCl}$ and determined by a spectrophotometer at wavelength of $540 \mathrm{~nm}$ with $\mathrm{N}$-(1naphthyl) ethylenediamine dihydrochloride. Apparent potential nitrification rates were calculated from the linear 
increase in concentrations of $\mathrm{NO}_{2}{ }^{-}$during the first $6 \mathrm{~h}$. The actual nitrification rates might be slightly higher owing to the possibility of denitrification, so the loss of $\mathrm{NO}_{2}{ }^{-}$cannot be fully excluded even in strictly oxic incubations.

\section{Statistical analysis}

The statistical analyses were conducted by Pearson correlation analysis with a computer program (SPSS, Statistical Product and Service Solutions). Correlation and graphing were achieved using SPSS v16.0 and Origin 7.5 software, respectively. The failure probability for small value of all significant differences was less than 0.05 .

Nucleotide sequence accession numbers

The archaeal amoA gene sequences obtained in this study are available in the GenBank nucleotide sequence database under Accession No. HM637849-HM637867 and HQ538539-HQ538572.

\section{Results}

Distribution and diversity of ammonia-oxidizing Archaea in sediments of wetlands

To investigate the existence of AOA and compare the AOA community in sediments of different wetlands with various heterogeneities, characteristic clone libraries of archaeal amoA genes were constructed. Overall, a total of 52 archaeal amo $A$ gene clone sequences were achieved based on the cloning library, and digestion pattern were subjected to BLAST search in the GenBank database, which confirmed that all sequenced clones represented amoA-like sequences. Meanwhile, another two biodiversity indexes, Chaol estimator and Shannon index were also calculated shown in Table 2. The results indicated that sediment of Baiyangdian Lake hold the highest OTU number of AOA amoA gene (ten OTUs calculated from 11 sequences), followed by Freshwater Marsh (nine OTUs from 10 sequences), Red Beach (eight OTUs from 11 sequences), and Paddy Field (six OTUs from 20 sequences). Chao1 estimator showed the similar trend and highest in freshwater marsh (23), followed by Red Beach (17), Baiyangdian Lake (15.5), and Paddy Field (6.33). So did Shannon index: Freshwater Marsh (2.16) $>$ Baiyangdian Lake (1.97) $>$ Red Beach(1.80) $>$ Paddy Field (1.49). From the above analysis, it can be concluded that AOA is most widely distributed in nitrogen-polluted wetland sediments, and the biodiversity of AOA in Baiyangdian Lake and Freshwater Marsh is highest, followed by Red Beach, and then Paddy Field.

Community analysis of ammonia-oxidizing Archaea in sediments of wetlands

The phylogenetic tree was constructed with the archaeal OTU sequences in this study and the relative sequences deposited in the gene bank, as shown in Fig. 1. The archaeal amoA functional gene sequences obtained in this study clustered as two major evolutionary branches: soil/ sediment and sediment/water. To be better analyzed, the phylogenetic tree was divided into six clusters further; the former four were subjected into soil/sediment branch, and the latter two were subjected into sediment/water branch.

The archaeal amoA functional gene sequences from Baiyangdian Lake, Red Beach, and Freshwater Marsh are only attached to soil/sediment branch (cluster 1-4) and corresponding affinity with sediment/water (clusters 5 and 6) is far. While sequences from Baiyangdian Lake are attached to cluster1, 2, and most is attached to cluster 1 (80.0\%), amoA gene sequences from Red Beach and Freshwater Marsh are all attached to all of the four clusters belonging to soil/sediment branch. This revealed that archaeal amoA functional gene sequences from Red Beach and Freshwater Marsh have a closer genetic relationship comparatively. It is probably due to the similarity of their geographic locations and natural environment. In contrast, archaeal amo $A$ functional gene sequences from Paddy Field distributes in both branches with majority attaching to sediment/water branch (clusters 5 and $6,33.3 \%$ and $50.0 \%$, respectively). This is probably attributed to long-term fertilized with biogas residue and waste liquor.

Table 2 Summary of archaeal amoA gene diversity in different sampling sites

\begin{tabular}{|c|c|c|c|c|c|}
\hline \multirow[b]{2}{*}{ Number of sequences } & & \multicolumn{4}{|c|}{ Sampling sites } \\
\hline & & $\begin{array}{l}\text { Red Beach } \\
11\end{array}$ & $\begin{array}{l}\text { Freshwater Marsh } \\
10\end{array}$ & $\begin{array}{l}\text { Baiyangdian Lake } \\
11\end{array}$ & $\begin{array}{l}\text { Paddy Field } \\
20\end{array}$ \\
\hline \multirow[t]{3}{*}{ Diversity of amoA gene } & OTUs number of AOA & 8 & 9 & 10 & 6 \\
\hline & Chaol estimate & $17(0.07)$ & $23(0.01)$ & $15.5(0.04)$ & $6.33(0.01)$ \\
\hline & Shannon index & $1.80(0.07)$ & $2.16(0.01)$ & $1.97(0.04)$ & $1.49(0.01)$ \\
\hline
\end{tabular}




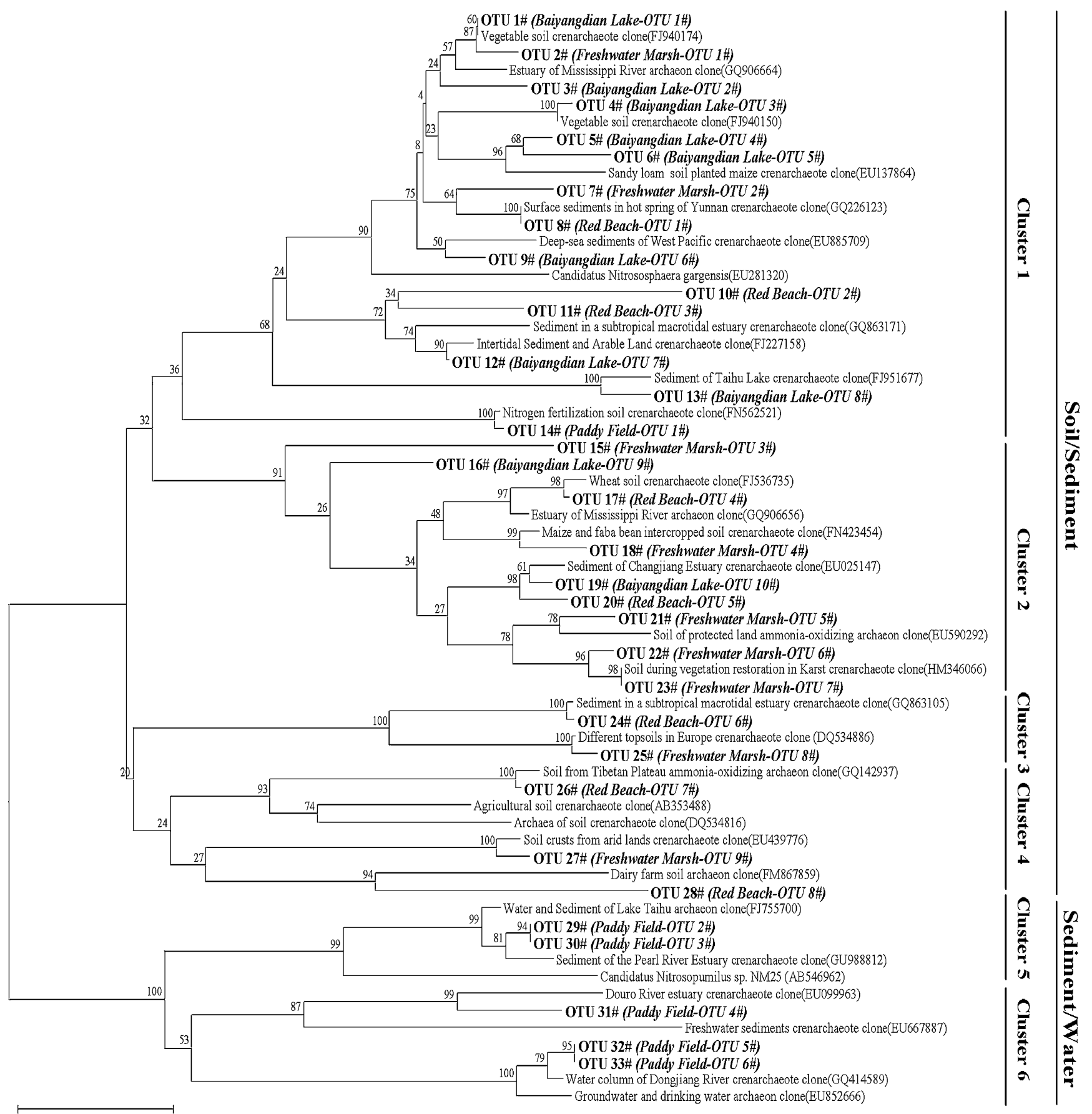

0.05

Fig. 1 Phylogenetic tree of the archaeal amoA gene sequences from sediments of Biayangdian Lake, Red Beach, Freshwater Marsh, and soil of Jiaxing Paddyfield. Note: This dendrogram was constructed by the NJ method; all reference sequences were gained from GenBank; two capital letters and six numbers in brackets represent the sequences

In addition, cluster 1 , containing the sequences from all of the four wetlands, showed Red Beach 37.5\%, Freshwater Marsh 22.2\%, Baiyangdian Lake 80.0\%, Paddy Field 16.7\%, and was predominant in Baiyangdian Lake (Table 3), indicating AOA of cluster 1 may be widely distributed in the accession number; the numbers close to the nodes represent the bootstrap values of 1,000 replications; the scale bar represents five nucleotide substitutions per 100 nucleotides. The detailed information of bacterial amoA gene clones of each OTU and accession numbers in Genbank are listed in supplement Table 1

wetlands. Cluster 2 was dominant exclusively in Freshwater Marsh (55.6\%), cluster 3 and 4 both only consisted of Red Beach and Freshwater Marsh and the cluster 5 and 6 were both dominant exclusively in Paddy Field. These all resulted from wetlands heterogeneity. 
Table 3 Quantitative analysis of archaeal amoA gene sequences composition in four polluted wetland sediments

\begin{tabular}{|c|c|c|c|c|c|}
\hline & & \multicolumn{4}{|l|}{ Sampling sites } \\
\hline & & Red Beach & Freshwater Marsh & Baiyangdian Lake & Paddy Field \\
\hline \multirow[t]{7}{*}{ Distribution (cluster) } & OTUs/all of OTUs & $8 / 33(24.2 \%)$ & $9 / 33(27.3 \%)$ & $10 / 33(30.3 \%)$ & $6 / 33(18.2 \%)$ \\
\hline & Cluster 1 & $3 / 8(37.5 \%)$ & $2 / 9(22.2 \%)$ & $8 / 10(80.0 \%)$ & $1 / 6(16.7 \%)$ \\
\hline & Cluster 2 & $2 / 8(25.0 \%)$ & $5 / 9(55.6 \%)$ & $2 / 10(20.0 \%)$ & 0 \\
\hline & Cluster 3 & $1 / 8(12.5 \%)$ & $1 / 9(11.1 \%)$ & 0 & 0 \\
\hline & Cluster 4 & $2 / 8(25.0 \%)$ & $1 / 9(11.1 \%)$ & 0 & 0 \\
\hline & Cluster 5 & 0 & 0 & 0 & $2 / 6(33.3 \%)$ \\
\hline & Cluster 6 & 0 & 0 & 0 & $3 / 6(50.0 \%)$ \\
\hline
\end{tabular}

Abundance analysis of $\mathrm{AOA}$ and $\mathrm{AOB}$ in sediments of wetlands

The abundance of AOA and AOB amoA gene were detected by real-time PCR in the four wetland sediments (Fig. 2). In general, the abundance of bacterial amoA gene was always higher than that of archaeal amo $A$ gene in the four sediments samples.

For the abundance of bacterial amoA gene, the Paddy Field soil showed the highest characteristic, followed by the Baiyangdian Lake, Red Beach, and Freshwater Marsh. The abundance of archaeal amoA gene showed the similar trend except the Freshwater Marsh. The sample of Baiyangdian Lake showed the highest gene number, followed by Paddy Field, Red Beach, and Freshwater Marsh. No matter which amoA gene taken into consideration, the abundance in Paddy Field and Baiyangdian Lake were always higher than that in Red Beach and Freshwater Marsh. The bacterial amoA functional gene abundance in Paddy Field is 3.31 times higher than that in Red Beach, and the archaeal amoA functional gene abundance in Baiyangdian Lake is 15.42 times higher than Freshwater Marsh's. As for the total abundance of amoA functional gene, including both AOA

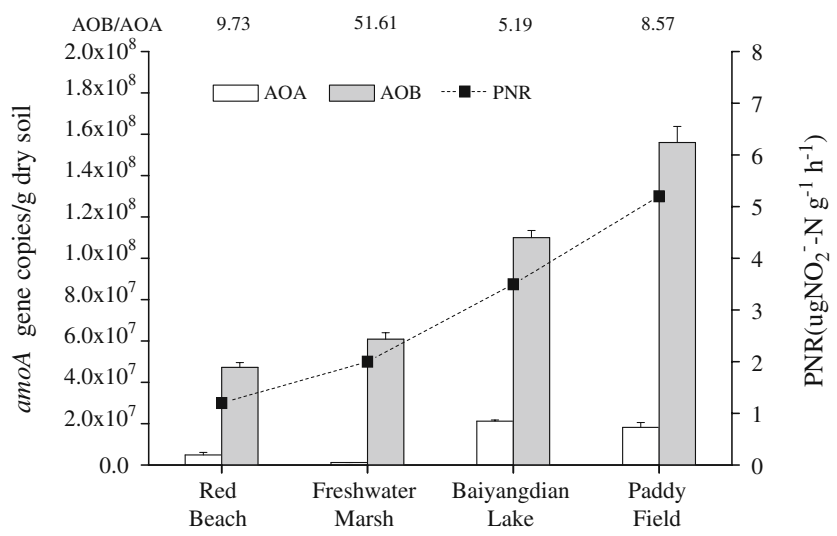

Fig. 2 The potential nitrification rates in sediments of four wetlands and the relevant archaeal and bacterial amo $A$ gene copy numbers. Error bars indicate standard deviation $(n=3)$ and AOB, Paddy Field is highest $\left(1.74 \times 10^{8}\right.$ copy numbers/ $\mathrm{g}$ dry soil) and is 3.35 times higher than that of Red Beach $\left(5.12 \times 10^{7}\right.$ copy numbers/g dry soil), which is lowest. Meanwhile, the relative amoA functional gene abundance (AOB/AOA) is also analyzed, and the results showed that Freshwater Marsh is the highest, followed by Red Beach, Paddy Field, and Baiyangdian Lake.

All the above clearly shows that $\mathrm{AOB}$ has higher abundance than AOA in nitrogen-rich wetland sediments; otherwise, AOA and AOB derived from different polluted wetland sediments held different abundance which may result from the heterogeneity in wetlands.

Potential nitrification rates (PNR) provide an independent estimate of the abundance of ammonia oxidizers. To determine PNR, intact sediment cores $(0-20 \mathrm{~cm})$ of each wetland were transported to the laboratory at ambient temperature $\left(22-24{ }^{\circ} \mathrm{C}\right)$. PNR of the four wetlands were determined after $48 \mathrm{~h}$ incubations and shown in Fig. 2. The lowest potential nitrification rate $\left(1.20 \mu \mathrm{gNO}_{2}^{-}-\mathrm{N} \cdot \mathrm{g}^{-1} \cdot \mathrm{h}^{-1}\right)$ was recorded in sediment of Red Beach. However, a PNR $\left(5.22 \mu \mathrm{gNO}_{2}{ }^{-}-\mathrm{N} \cdot \mathrm{g}^{-1} \cdot \mathrm{h}^{-1}\right)$ that was almost five times higher than that of Red Beach was measured in sediment of Paddy Field, followed by Baiyangdian Lake (3.50 $\mathrm{\mu gNO}_{2}^{-}$ $\left.\mathrm{N} \cdot \mathrm{g}^{-1} \cdot \mathrm{h}^{-1}\right)$ and Freshwater Marsh (2.03 $\mathrm{\mu gNO}_{2}{ }^{-}$ $\mathrm{N} \cdot \mathrm{g}^{-1} \cdot \mathrm{h}^{-1}$ ). Moreover, the higher PNR in the sediment, the higher relative abundance of bacterial amoA gene, but not archaeal amoA gene. These results provide strong indication that ammonia-oxidizing bacteria dominate the nitrification in sediments of nitrogen-rich wetlands.

Factors influencing bacterial and archaeal amo $A$ gene abundance in sediments of wetlands

In order to investigate the reason of abundance difference, the environmental factors were analyzed combined with the copy numbers of archaeal and bacterial amoA gene. The correlation analyses were carried out between every two factors involved in the test (Table 4). The results addressed the copy numbers of archaeal and bacterial amo $A$ functional 
gene is correlated with environmental factors, especially with $\mathrm{pH}$ and ammonia concentration. The $\mathrm{pH}$ had relatively great negative impact on the abundance of AOA and AOB, while ammonia concentration had positive impact on bacterial abundance exclusively. In other words, the ammonia concentration provided positive impact on the difference between archaeal and bacterial abundance.

To fully address the influence of ammonia concentration and $\mathrm{pH}$ value on abundance of $\mathrm{AOA}$ and $\mathrm{AOB}, \mathrm{pH}$ and ammonia concentration vs. archaeal and bacterial amo $A$ functional gene copy numbers (in log scale) of four wetland sediments was plotted into supplement Fig. 1. From the figure, it's proven that $\mathrm{pH}$ showed evidently negative influence on no matter archaeal or bacterial abundance. Bacterial amoA functional gene abundance increased significantly with increasing of ammonia content, while archaeal amoA functional gene abundance was maintained almost unchanged.

\section{Discussion}

With the finding of amoA functional gene in Crenarchaeota (Venter et al. 2004), various researches findings showed there is abundant AOA in some soil and marine ecosystems (Leininger et al. 2006; Wuchter et al. 2006). In our study, it's pointed out that the AOA is rich in ammonia-polluted wetland ecosystems which exhibited higher biodiversity and abundance in the range of $1.18 \times 10^{6}-2.12 \times 10^{7}$ copy numbers/g dry soil. That is, AOA can be found extensively in wetlands sediments and play a key role during ammonia oxidation. Moreover, the content of AOA and AOB in wetlands were obviously higher than that in high-altitude soils of Mount Everest (AOA, $4.63 \times 10^{3}-2.72 \times 10^{4}$ copy numbers/g soil; AOB, $5.41 \times 10^{4}-3.1 \times 10^{6}$ copy numbers/g soil), and abundance of AOB was higher than that in agricultural soil $(2.5 \times$ $10^{6}$ copy numbers/g soil; Zhang et al.2009; Jia et al. 2009). In other words, the high abundance of amoA functional gene proved wetlands playing an important role in natural nitrogen cycle.

Following the discovery of amo $A$ of the marine group 1 Crenarchaeota (Könneke et al. 2005), Leininger et al. (2006) and Wuchter et al. (2006) reported that the Archaea predominate among ammonia-oxidizing prokaryotes in soils and marine, respectively. Herrmann et al. (2008) showed that Archaea dominate the ammonia-oxidizing community in the rhizosphere of the freshwater. Jia and Conrad (2009) found that the abundances of AOA at the depth of $0-20 \mathrm{~cm}$ and $40-50 \mathrm{~cm}$ in an agricultural soil were much higher than that of AOB. It seemed that AOA predominate among ammoniaoxidizing prokaryotes in nature. But, there are still some researches verified that $\mathrm{AOB}$ with higher bacterial functional gene number plays a more important role in ammonia oxidation in nitrogen-rich soil ( $\mathrm{Di}$ et al. 2009) and river sediments (Fan et al. 2010). This study is the first one to investigate $\mathrm{AOA}$ and $\mathrm{AOB}$ in the ammonia-polluted wetlands sediments, and the results showed the abundance of AOB were all much higher that of AOA. The PNR were also measured at the same time of AOA and AOB abundance analysis. Compared with other studies, the PNR (1.2-5.2 $\left.\mathrm{ugNO}_{2}{ }^{-}-\mathrm{N} \cdot \mathrm{g}^{-1} \cdot \mathrm{h}^{-1}\right)$ in sediments of ammonia-polluted wetland was higher than the soil treatments $\left(0.09-2.54 \mathrm{ugNO}_{2}^{-}\right.$ $\mathrm{N} \cdot \mathrm{g}^{-1} \cdot \mathrm{h}^{-1}$, Shen et al. 2008; 0.067-0.7 $\mathrm{mg} \mathrm{NO}{ }_{3}^{-}-\mathrm{N} \cdot \mathrm{g}^{-1} \cdot \mathrm{h}^{-1}$, Jia and Conrad 2009). Moreover, the higher nitrification rates in the sediment coincided with higher relative abundances of $\mathrm{AOB}$ but not $\mathrm{AOA}$, which illustrated that $\mathrm{AOB}$ maybe contribute more to ammonia oxidation than $\mathrm{AOA}$ in the ammonia-polluted wetlands.

Although the key factor influencing AOA and AOB is still not well understood and difficult to assess (Erguder et al. 2009), the $\mathrm{pH}$ value seems to be one of the most important factors based on this study findings. The quantitative results from samples of four wetlands sediments show $\mathrm{pH}$ was strong correlated with the abundance of AOB and AOA. This

Table 4 The correlation coefficients between chemical property and amoA functional gene abundance of AOB and AOA

\begin{tabular}{|c|c|c|c|c|c|c|c|c|c|}
\hline Item & $\mathrm{AOA}$ & $\mathrm{AOB}$ & $\mathrm{AOB}-\mathrm{AOA}$ & TOM & $\mathrm{NH}_{4}^{+}-\mathrm{N}$ & $\mathrm{NOx}^{-}-\mathrm{N}$ & TKN & $\mathrm{pH}$ & Water content \\
\hline $\mathrm{AOA}$ & 1 & & & & & & & & \\
\hline $\mathrm{AOB}$ & 0.836 & 1 & & & & & & & \\
\hline $\mathrm{AOB}-\mathrm{AOA}$ & 0.758 & $0.992^{\mathrm{b}}$ & 1 & & & & & & \\
\hline TOM & 0.476 & 0.837 & 0.883 & 1 & & & & & \\
\hline $\mathrm{NH}_{4}{ }^{+}-\mathrm{N}$ & 0.799 & $0.990^{\mathrm{a}}$ & $0.989^{\mathrm{a}}$ & 0.804 & 1 & & & & \\
\hline $\mathrm{NOx}^{-}-\mathrm{N}$ & 0.577 & 0.873 & 0.902 & $0.990^{\mathrm{b}}$ & 0.829 & 1 & & & \\
\hline TKN & 0.564 & 0.892 & 0.928 & $0.994^{\mathrm{b}}$ & 0.862 & $0.994^{\mathrm{b}}$ & 1 & & \\
\hline $\mathrm{pH}$ & $-0.951^{\mathrm{a}}$ & $-0.953^{\mathrm{a}}$ & -0.908 & -0.641 & -0.944 & -0.708 & -0.722 & 1 & \\
\hline Water content & -0.485 & -0.835 & -0.879 & $-1.000^{\mathrm{b}}$ & -0.799 & $-0.993^{\mathrm{b}}$ & $-0.993^{b}$ & 0.642 & 1 \\
\hline
\end{tabular}

${ }^{\text {a }}$ Correlation is significant at the 0.05 level (two-tailed)

${ }^{\mathrm{b}}$ Correlation is significant at the 0.01 level (two-tailed) 
indicates that soil $\mathrm{pH}$ could have a major effect on the population sizes of $\mathrm{AOB}$ and $\mathrm{AOA}$ in the soil although the $\mathrm{pH}$ ranges a small unit from 8.2 to 8.4 , which was in agreement with previous observations (He et al. 2007; Shen et al. 2008; Erguder et al. 2009). It is interesting to note that the ammonia, as the common substrate, showed the different influence on AOA and AOB population size. The bacterial amoA gene copy numbers and nitrification activity were all increased with increasing of substrate ammonia concentration. The previous studies also find that, in relative high substrate ammonia condition, not only the bacterial AOB population size (Oved et al. 2001; Okano et al. 2004) but also the nitrification activity (Avrahami et al. 2002) were all increased with increasing soil ammonia concentration, even with $7.5 \mathrm{mM}$ ammonium sulfate. But, the archaeal amoA gene copy numbers showed little relationship with increasing ammonia concentration, which was similar with the other results of $\mathrm{He}$ et al. (2007), Shen et al. (2008), and Di et al. (2009). When ammonia concentration is limiting factor, the value of archaeal $\mathrm{K}_{\mathrm{S}}(133 \mathrm{nM})$ becomes substantial for the AOA predominance from the aspect of biochemistry kinetics (Martens et al. 2009). Because the value of bacterial $K_{\mathrm{S}}\left[K_{\mathrm{S}}\right.$ values in soil for Nitrosospira sp. AV and Nitrosospira europaea were estimated at 0.14 and $1.9 \mathrm{mM} \mathrm{NH}_{4}{ }^{+}$, respectively (Anne et al. 2006)] is much higher than that of archaeal, the AOA would outcompete when facing the limited substrate ammonia. Oppositely, the research results of Hatzenpichler and colleagues (2008) showed that high concentration of ammonia $(3.08 \mathrm{mM})$ would inhibit the ability of thermophilic ammoniaoxidizing crenarchaeote to oxidized ammonia, which is the key factor for bacterial predominance under high ammonia circumstances.

Taken together, these research results indicate that Bacteria rather than Archaea functionally dominated microbial ammonia oxidation in surface sediments of nitrogen-rich wetlands on the basis of molecule analysis, nitrification rate, and soil chemistry. The $\mathrm{pH}$ showed the negative impact on abundance of bacterial and archaeal amoA functional gene, but ammonia concentration exhibited the positive influence on AOB not AOA.

Acknowledgments The authors would like to thank Profs. Junxin Liu, He Jizheng and Weidong Wang for their kind help; Xiangchong Liu are gratefully acknowledged for his detailed and patient favor in correlation analysis. This research is financially supported by the National Natural Science Foundation of China (20877086 and 21077119), National Basic Research Program of China (No.2009CB421103), and National Water Project (2008ZX07209006-02; 2008ZX07421-001; 2009ZX07209-005).

\section{References}

Anne ET, Peter JB (2006) Nitrite production by Nitrosomonas europaea and Nitrosospira sp. AV in soils at different solution concentrations of ammonium. Soil Biol Biochem 38(4):828-836
Avrahami S, Conrad R, Braker G (2002) Effect of soil ammonium concentration on $\mathrm{N}_{2} \mathrm{O}$ release and on the community structure of ammonia oxidizers and denitrifiers. Appl Environ Microbiol 68 (11):5685-5692

Bao SD (2000) Soil and Agricultural Chemistry Analysis (3th Eidtion). China Agriculture, Beijing

Caffrey J, Bano N, Kalanetra K, Hollibaugh J (2007) Ammonia oxidation and ammonia-oxidizing bacteria and Archaea from estuaries with differing histories of hypoxia. ISME J 1:660-662

Di HJ, Cameron KC, Shen JP, Winefield CS, O'Callaghan M, Bowatte S, He JZ (2009) Nitrification driven by bacteria and not Archaea in nitrogen-rich grassland soils. Nat Geosci 2:621-624

Erguder TH, Boon N, Wittebolle L, Marzorati M, Verstraete W (2009) Environmental factors shaping the ecological niches of ammonia oxidizing Archaea. FEMS Microbiol Rev 33(5):855-869

Fan GN, Zhu GB, Wang Y, Wang SY, Wang CX, Yin CQ (2010) New functional microorganisms in nitrogen cycle restoration of river riparian ecosystems. Acta Scientiae Circumstantiae 30(8):15581563

Francis CA, Roberts KJ, Beman JM, Santoro AE, Oakley BB (2005) Ubiquity and diversity of ammonia-oxidizing Archaea in water columns and sediments of the ocean. Proceedings of the National Academy of Sciences 102(41):14683-14688

Gruber N, Galloway JN (2008) An Earth-system perspective of the global nitrogen cycle. Nature 451:293-296

Hatzenpichler R, Lebedeva EV, Spieck E, Stoecker K, Richter A, Daims H, Wagner M (2008) A moderately thermophilic ammonia-oxidizing crenarchaeote from a hot spring. Proc Natl Acad Sci USA 105(6):2134-2139

He J, Shen J, Zhang L, Zhu Y, Zheng Y, Xu M, Di HJ (2007) Quantitative analyses of the abundance and composition of ammonia-oxidizing bacteria and ammonia-oxidizing Archaea of a Chinese upland red soil under long-term fertilization practices. Environ Microbiol 9(9):2364

Herrmann M, Saunders AM, Schramm A (2008) Archaea dominate the ammonia-oxidizing community in the rhizosphere of the freshwater macrophyte Littorella uniflora. Appl Environ Microbiol 74(10):3279-3283

Jia ZJ, Conrad R (2009) Bacteria rather than Archaea dominate microbial ammonia oxidation in an agricultural soil. Environ Microbiol 11(7):1658-1671

Jiang H, Dong H, Yu B, Lv G, Deng S, Berzins N, Dai M (2009) Diversity and abundance of ammonia-oxidizing Archaea and bacteria in Qinghai Lake, northwestern China. Geomicrobiol J 26:199-211

Könneke M, Bernhard A, de la Torre JR, Walker CB, Waterbury JB, Stahl DA (2005) Isolation of an autotrophic ammonia-oxidizing marine archaeon. Nature 437(22):543-546

Kurola J, Salkinoja-Salonen M, Aarnio T, Hultman J, Romantschuk M (2005) Activity, diversity and population size of ammoniaoxidising bacteria in oil-contaminated landfarming soil. FEMS Microbiol Lett 250:33-38

Leininger S, Urich T, Schloter M, Schwark L, Qi J, Nicol GW, Prosser JI, Schuster SC, Schleper C (2006) Archaea predominate among ammonia-oxidizing prokaryotes in soils. Nature 442:806-809

Martens-Habbena W, Berube PM, Urakawa H, de la Torre JR, Stahl DA (2009) Ammonia oxidation kinetics determine niche separation of nitrifying Archaea and Bacteria. Nature 461:976-979

Mosier A, Francis C (2008) Relative abundance and diversity of ammonia-oxidizing Archaea and bacteria in the San Francisco Bay estuary. Environ Microbiol 10:3002-3016

Okano Y, Hristova KR, Leutenegger CM, Jackson LE, Denison RF, Gebreyesus B, David L, Scow KM (2004) Application of realtime PCR to study effects of ammonium on population size of ammonia-oxidizing bacteria in soil. Appl Environ Microbiol 70 (2):1008-1016 
Oved T, Shaviv A, Goldrath T, Mandelbaum RT, Minz D (2001) Influence of effluent irrigation on community composition and function of ammonia-oxidizing bacteria in soil. Appl Environ Microbiol 67(8):3426-3433

Park HD, Wells GF, Bae H, Criddle CS, Francis CA (2006) Occurrence of ammonia-oxidizing Archaea in wastewater treatment plant bioreactors. Appl Environ Microbiol 72(8):56435647

Peng Yongzhen and Zhu Guibing (2006) Biological nitrogen removal with nitrification and denitrification via nitrite pathway. Appl Microbiol Biotechnol 73(1):15-26

Prosser JI (1989) Autotrophic nitrification in bacteria. Adv Microb Physiol 30:125-181

Prosser JI, Nicol GW (2008) Relative contributions of Archaea and bacteria to aerobic ammonia oxidation in the environment. Environ Microbiol 10(11):2931-2941

Santoro A, Francis C, de Sieyes N, Boehm A (2008) Shifts in the relative abundance of ammonia-oxidizing bacteria and Archaea across physicochemical gradients in a subterranean estuary. Environ Microbiol 10:1068-1079

Schloss PD, Handelsman J (2005) Introducing DOTUR, a computer program for defining operational taxonomic units and estimating species richness. Appl Environ Microbiol 71:1501-1506

Shen JP, Zhang LM, Zhu YG, Zhang JB, He JZ (2008) Abundance and composition of ammonia-oxidizing bacteria and ammoniaoxidizing Archaea communities of an alkaline sandy loam. Environ Microbiol 10(6):1601-1611

Tamura K, Dudley J, Nei M, Kumar S (2007) MEGA4: molecular evolutionary genetics analysis (MEGA) software version 4.0. Mol Biol Evol 24:1596

Thompson JD, Gibson TJ, Plewniak F, Jeanmougin F, Higgins DG (1997) The CLUSTALX windows interface: flexible strate-gies for multiple sequence alignment aided by quality analysistools. Nucleic Acids Res 25:4876-4882

Venter JC, Remington K, Heidelberg JF, Halpern AL, Rusch D, Eisen JA, Wu D, Paulsen I, Nelson KE, Nelson W, Fouts DE, Levy S, Knap AH, Lomas MW, Nealson K, White O, Peterson J, Hoffman J, Parsons R, Baden-Tillson H, Pfannkoch C, Rogers YH, Smith HO (2004) Environmental genome shotgun sequencing of the Sargasso sea. Science 304:66-74

Verhoeven JTA, Arheimer B, Yin C, Hefting MM (2006) Regional and global concerns over wetlands and water quality. Trends Ecol Evol 21(2):96-103

Wang H, Wang W, Yin C, Wang Y, Lu J (2006) Littoral zone as the "hotspots" of nitrous oxide $\left(\mathrm{N}_{2} \mathrm{O}\right)$ emission in a hyper-eutrophic lake in China. Atmos Environ 40:5522-5527

Wang H, Yang L, Wang W, Lu J, Yin C (2007) Nitrous oxide $\left(\mathrm{N}_{2} \mathrm{O}\right)$ fluxes and their relationship with water-sediment parameters in a hyper-eutrophic shallow Lake, China. J Geophys Res 112: G01005. doi:10.1029/2005JG000129

Wuchter C, Abbas B, Coolen MJL, Herfort L, van Bleijswijk J, Timmers P, Strous M, Teira E, Herndl GJ, Middelburg JJ, Schouten S, Damste JSS (2006) Archaeal nitrification in the ocean. Proceedings of the National Academy of Sciences 103(33):12317-12322

Zhang CL, Ye Q, Huang Z, Li W, Chen J, Song Z, Zhao W, Bagwell C, Inskeep WP, Ross C, Gao L, Wiegel J, Romanek CS, Shock EL, Hedlund BP (2008) Global occurrence of archaeal amoA genes in terrestrial hot springs. Appl Environ Microbiol 74(20):6417-6426

Zhang L, Wang M, Prosser J, Zheng Y, He J (2009) Altitude ammonia-oxidizing bacteria and Archaea in soils of Mount Everest. FEMS Microbiol Ecol 70:52-61

Zhu G, Peng Y, Li B, Guo J, Yang Q, Wang S (2008) Biological removal of nitrogen from wastewater. Reviews of Environmental Contamination and Toxicology. 159-195. 